\title{
THE IMPACT OF DEMOGRAPHIC AND SOCIO-PSYCHOLOGICAL CHARACTERISTICS ON CONSUMERS' ETHNOCENTRIC TENDENCIES: EVIDENCE FROM CROATIA
}

\author{
Antonija Kvasina* \\ Biljana Crnjak-Karanovic** \\ Ante Tucak***
}

Received: 14. 6. 2018

Preliminary communication

Accepted: 28. 11. 2018

UDC 366.1:314.04-057.68

DOI https://doi.org/10.30924/mjcmi/2018.23.2.47

\begin{abstract}
The objective of this study is to determine the impact of demographic and sociopsychological characteristics on consumers' ethnocentric tendencies. The research was conducted within Croatia among the residents living in the Split-Dalmatia County. The data was collected from 420 respondents using a questionnaire based on the CETSCALE measurement. Hypotheses were tested in order to investigate differences in consumers' ethnocentric tendencies with regar$d s$ to two demographic characteristics (age and level of education) and two socio-psychological characteristics (foreign travel experience and interest to travel abroad). Both hypotheses related to age and education were supported. Moreover, the findings show that respondents with higher
\end{abstract}

\section{INTRODUCTION}

Due to the process of internationalization and globalization, consumers are able to reach the vast majority of products available today in the consumer world, thus meeting their needs and taking up opportunities to enjoy different lifestyles, cultures, level of education have higher tendencies of consumer ethnocentrism than those with lower level of education. Findings also show that younger people have more pronounced tendencies of consumer ethnocentrism than older people, which is not in accordance with previous research. Both hypotheses of the socio-psychological characteristics were also supported. The research suggests that people traveling abroad and having a more expressed interest to travel abroad have a higher degree of consumer ethnocentrism than those who travel less and have a lower desire to travel abroad.

Keywords: ethnocentrism, consumers, demographics, socio-psychological, charachteristics, travel

new products, and ideas. It was expected that globalization would lead to product homogeneity because of the development of the world economy, but this did not happen. Globalization does not lead to product homogeneity due to cultural differences (Mooij \& Hofstede, 2002).

\footnotetext{
* Antonija Kvasina, Assistant, Faculty of Economics, Business and Tourism Split, Croatia, e-mail: antonija.kvasina@ efst.hr, phone: +38521430696

** Biljana Crnjak Karanović, Professor, Faculty of Economics, Business and Tourism Split, Croatia, e-mail: biljana. crnjak-karanovic@efst.hr, phone: +38521430652

*** Ante Tucak, mag. oec., graduated student of Faculty of Economics, Business and Tourism, University of Split, Croatia, e-mail: tucak.ante@gmail.com
} 
Therefore, the success of a company when operating abroad depends on the ability to understand and meet the needs of host country customers (Crnjak-Karanović \& Miočević, 2013). This can be a problem and a challenge if consumers are ethnocentric (Klein, 2002). Academics have proved that, even though ethnocentrism is a global phenomenon, there are differences in the level of ethnocentrism expressed by consumers across different cultures and countries (Javalgi et al., 2005). Moreover, it has been demonstrated that consumers from developed countries are less ethnocentric than consumers from developing or emerging countries (Sharma et al., 1995; Javalgi et al., 2005).

The ethic sentiment has become one of the most profound motivations for consumer buying behaviour, especially in the economies that are going through the process of major reforms, such as various countries in Central and Eastern Europe (Vida \& Fairhurst, 1999). Numerous studies have been conducted in order to identify factors that are related to the assessment and selection of domestic products in relation to foreign ones, with the purpose of identifying and creating patterns of consumer behaviour.

Consumer ethnocentrism $(\mathrm{CE})^{1}$ is an important factor in the research on consumer behaviour in the global market, especially when researching purchase decisions between local and foreign products (Alshammari et al., 2017). CE is a concept that includes individual consumer's beliefs about the correctness and morality of buying domestic products at the expense of foreign products (Shimp \& Sharma, 1987). Crawford \& Lamb (1981), when studying $\mathrm{CE}$, pointed out that purchasing foreign products can cause high emotional involvement, especially if national security or job losses are concerned, which led to the introduction of the concept of ethnocentrism beyond psychological and sociological frameworks as one of the most important factors in consumer buying choice (Renko et al., 2012).

Croatia represents an interesting research setting since it is a developing country that recently entered the European Union $(\mathrm{EU})^{2}$. Companies that are offering their products across various EU markets need to deal with various levels of ethnocentrism (Javalgi et al., 2005) on those markets. Moreover, Javalgi et al. (2005) emphasized the challenges that marketers face in the EU market, such as holding on to each country's cultural heritage.

It is evident that $\mathrm{CE}$ is highly important for both marketing academics and practitioners.

However, explanations of the intensity of CE are linked to the underlying assumptions that this concept does not act alone, but under the influence of certain conditions. In their work, Sharma et al. (1995) emphasized that ethnocentric preferences among consumers are not being developed in isolation, but are part of a set of sociopsychological, economic, political, and demographic effects. Consequently, despite numerous researches there will always be a need to clarify and/or cement findings concerning $\mathrm{CE}$.

The objective of this study is to understand the degree of CE in Croatia, a developing country that recently entered the developed EU market. Creating an overall image of consumers' ethnocentric tendencies

\footnotetext{
In the continuation of the paper, instead of "consumer ethnocentrism" the abbreviation "CE" will be used.

2 In the continuation of the paper, instead of "European Union" the abbreviation "EU" will be used.
} 
will be achieved by examining the relationships between demographic and socio-psychological characteristics and the consumers' ethnocentric tendencies. Consumers' demographic factors (age and level of education) and their correlation with $\mathrm{CE}$ will help to create a better image of ethnocentric behaviour. The link between socio-psychological consumer factors (foreign travel experience and interest to travel abroad) and consumers' ethnocentric tendencies will give a final picture of the ethnocentricity of consumers.

There has been little research in Croatia regarding the consumers' ethnocentric tendencies, especially when related to demographic and socio-psychological factors. Matić (2012) conducted a study in Northern Croatia and invited for further research in other Croatian regions. Therefore, additional value of this paper is that it focuses on a specific Croatian region - Split-Dalmatia County, where consumers' ethnocentric tendencies have not been researched yet.

\section{LITERATURE REVIEW}

The concept of ethnocentrism was introduced by sociologist Sumner in 1906 (Adorno et al., 1950 in Shimp, 1984) when it was defined as a view of the world in which one's own group of people are in the centre of everything and everyone else is observed with respect to them. Ethnocentrism was first studied in the 1970s by sociologists who believed that a person gives privileged treatment to members of the groups they belong to (Javalgi et al., 2005). Ethnocentric behaviour is viewed as a tendency to accept those who are culturally similar and reject those who are not. "Ethnocentrism was originally conceptualized as a purely sociological concept that distinguished in-groups (those groups with which an individual identifies) from out-groups (those regarded as antithetical to the in-groups)" (Shimp, 1984:285). Ethnocentrism implicates strong pro-ingroup feelings combined with strong antiout-group feelings (Adorno et al. 1950 in Shimp, 1984).

The CE, from the consumer behaviour perspective, was first presented by Shimp (1984) who outlined that "ethnocentric consumers believe it is wrong to purchase foreign-made products because it will hurt the domestic economy, cause the loss of jobs, and it is plainly unpatriotic" (p.285). Based on these insights, Shimp \& Sharma (1987) also stressed out that consumers who are inclined towards ethnocentric behaviour evaluate products according to their own individual beliefs about the positive or negative effects on the development of domestic economy.

Causes of ethnocentrism are psychological, interpersonal and related to the sociostructural sphere (Balabanis et al., 2002). Ethnocentrism can be a "self-defense reflex of local economies, governments, organizations, and individuals against the threat of imports and foreign competition" (Siamagka \& Balabanis, 2015:66).

It is thought to be a personality trait that affects "an individual's attitudes, intentions, preferences and purchase behavior with respect to imported vs. competing domestic products" (Vida \& Fairhurst, 1999:323). Opposite to attitudes that have an evaluative character, when defining $\mathrm{CE}$, it is more appropriate to use the term "tendency" because the term "conveys that ethnocentric tendencies are more durable and stable than attitudes" (Balabanis \& Siamagka, 2017:167).

Alsughayir's (2013) literature review revealed that $\mathrm{CE}$ has been studied in relation to various variables: domestic purchase behaviour (Dmitrovic et al., 2009), 
purchase intentions (Renko et al., 2012), willingness to buy imported products and product judgments (Klein et al., 1998) or attitudes towards importing products (Sharma et al., 1995. Moreover, it was also studied with respect to the awareness of the country of origin (McLain \& Sternquist, 1991), patriotism, nationalism and internationalism (Balabanis et al., 2001), human values (Balabanis et al., 2002), dogmatism and social class variables (Caruana \& Magri, 1996), cosmopolitanism (Vida \& Reardon, 2008) and brand awareness (Vida \& Fairhurst, 1999).

Also, many academics researched how the economic development and an individual country's circumstances (Sharma et al., 1995; Klein \& Ettenson, 1999) or the political environments (Alshammari et al., 2017) affect the ethnocentric tendencies. Park \& Yoon (2017) in Acikdilli et al. (2018) stated that consumers' ethnocentric tendencies rise in the occurrence of a perceived threat, e.g. unfair economic trade, political disputes or a hostile memory of an armed conflict.

By reviewing recent literature, Siamagka \& Balabanis (2015) pointed out that $\mathrm{CE}$ is also significant for global positioning, global branding, market entry decisions, and the appearance of country-oforigin effects. To examine the consequences of ethnocentrism, researchers have posited that certain variables such as product necessity, product serviceability, country-oforigin, and consumer animosity have an effect on the relationships between ethnocentrism and attitude and, in turn, attitude and purchase intention (Javalgi et al., 2005). Finally, Javalgi et al. (2005) outlined that consumers also may have strong negative feelings against one or more nations for historic reasons.

In order to better understand the complexity of consumer behaviour, researchers also focused on relating the $\mathrm{CE}$ to various demographic and socio-psychological factors. Shimp (1984) was the first author to propose that there is a clear difference between ethnocentric and non-ethnocentric consumer in various contexts, such as educational achievements or income levels. Moreover, he stated that ethnocentric consumers are generally the ones with lower education or income. Relying on previous research, Acikdilli et al. (2018) pointed out that, in order to understand differences in consumer behaviour, it is important to research only demographic data and characteristics, such as age, gender or religion, that are important when trying to predict consumer behaviour (Gonzales \& Bello, 2002; in Acikdilli et al., 2018). Shankarmahesh (2006) gave an integrative review of antecedents and consequences of CE. He pointed out there were four groups of key antecedents of CE: (1) socio-psychological, (2) economic, (3) political, and (4) demographic. These assumptions are crucial for identifying the consumer's ethnocentric profile.

\subsection{Demographic variables and ethnocentrism}

Research has shown that the underlying demographic variables, such as age, gender, income and degree of education, affect the intensity of CE (Acikdilli et al., 2018; Han, 2016) and that there are differences in the degree of CE with respect to different demographic characteristics (Vida \& Fairhurst, 1999).

Josiassen et al. (2011) emphasized the importance of studying the effect of demographic characteristics on consumers' behaviour due to the fact they were easier to measure and handle, meaning they increased managerial relevance of $\mathrm{CE}$ studies that included demographic characteristics (Homburg \& Giering, 2001 in Josiassen et al., 2011). 
In previous researches, the hypothesized relationships were mostly consistent; however, some researchers have not been able to prove the statistical significance of the proposed relationships. Many academics have researched various demographic factors (Matić, 2012; McLain \& Sternquist, 1991). It has been shown that older consumers, mostly female, are most commonly ethnocentric consumers (Vida \& Fairhurst, 1999) and that people with high levels of CE were more likely to be less educated (Watson \& Wright, 2000; Good \& Huddleston, 1995). There were also findings that were not in accordance with the aforementioned results (Sharma et al., 1995).

\subsection{Socio-psychological variables and ethnocentrism}

Various socio-psychological characteristics could influence CE (Alsughayir, 2013). According to Alshammari et al. (2017) there are four most researched components of socio-psychological antecedents: animosity, conservatism, cultural openness, and patriotism. Shankarmahesh (2006) also reviewed dogmatism, salience, list of values, materialism, world mindedness, and collectivism-individualism.

Some authors indicate that lower level of inter-cultural knowledge will result in a more pronounced ethnocentrism (Devine, 1989 in Alsughayir, 2013), which was also supported by Bush \& Ingram (1996 in Alsughayir, 2013), stating that if a person has less cross-cultural interaction and knowledge, the more expressed their ethnocentrism will be.

Sharma et al. (1995) found a negative link between cultural openness and CE. Cultural openness is defined as readiness to interact with other cultures and to try or experience some of their products or services (Sharma et al., 1995), implying that if someone is more open-minded, the level of ethnocentrism will be lower. However, it is not reasonable to simplify the aforementioned connection in such a manner and to state that cross-cultural interactions will mitigate ethnocentric tendencies (Shankarmahesh, 2006).

The globalization of media and Internet development highly contributed to enhancing cultural openness (Javalgi et al., 2005). Earlier studies showed that if a consumer has been more exposed to foreign cultures, the more he was willing to accept foreign (imported) products (Howard, 1989; in Javalgi et al., 2005). On the other hand, Balabanis et al. (2001) did not find a link between ethnocentrism and internationalism. However, Javalgi et al. (2005) outlined that cultural openness was independent from ethnocentrism when researching $\mathrm{CE}$ in France. They pointed out the difference between these two concepts, emphasizing that internationalism is more concerned with the welfare of foreign countries' population and therefore, does not have a strong impact on personal level, such as making a purchasing decision.

As an important socio-psychological characteristic, several authors researched the impact of traveling on CE (Jain \& Jain, 2010; Jain \& Jain, 2013). Cultural openness can increase from more interaction with foreigners or by traveling overseas (Jain \& Jain, 2013) which is why travel experience represents a significant role in cultural openness, because it enables open-mindedness (Belk, 1998 in Siamagka \& Balabanis, 2015).

Therefore, this study focuses on exploring the differences in consumers' ethnocentric tendencies in relation to demographic and socio-psychological characteristics. Demographic characteristics that have been 


\section{Journal of Contemporary Management Issues}

Table 1. Literature review on demographic and socio-psychological characteristics related to consumers' ethnocentric tendencies

\begin{tabular}{|c|c|c|}
\hline CHARACTERISTICS & AUTHORS \& YEAR & $\begin{array}{c}\text { GENERAL } \\
\text { CONCLUSIONS }\end{array}$ \\
\hline Age & $\begin{array}{l}\text { McLain \& Sternquist, 1991; Sharma et al., 1995; } \\
\text { Good \& Huddleston, 1995; Caruana \& Magri, } \\
\text { 1996; Vida \& Fairhurst, 1999; Klein \& Ettenson, } \\
\text { 1999; Balabanis et al., 2002; Bawa, 2004; Javalgi } \\
\text { et al., 2005; Matić, 2012; Jain \& Jain, 2013; Sia- } \\
\text { magka \& Balabanis, 2015 }\end{array}$ & $\begin{array}{l}\text { CE is more expressed } \\
\text { among older people }\end{array}$ \\
\hline Level of education & $\begin{array}{l}\text { McLain \& Sternquist, 1991; Sharma, et al., 1995; } \\
\text { Caruana \& Magri, 1996; Klein \& Ettenson, 1999; } \\
\text { Good \& Huddleston, 1995; Balabanis et al., 2002; } \\
\text { Bawa, 2004; Javalgi et al., 2005; Matić, 2012; Jain } \\
\text { \& Jain, 2013; Siamagka \& Balabanis, 2015 }\end{array}$ & $\begin{array}{l}\text { CE is more expressed } \\
\text { among people with lower } \\
\text { level of education }\end{array}$ \\
\hline Interest to travel abroad & Nijssen et al., 1999 & Negative correlation \\
\hline Foreign travel experience & $\begin{array}{l}\text { Neuliep et al., 2001; Jain \& Jain, 2010; Jain \& Jain, } \\
2013\end{array}$ & $\begin{array}{l}\text { There is no significant } \\
\text { influence }\end{array}$ \\
\hline
\end{tabular}

Source: Adapted and complemented from Alsughayir, A. (2013) Consumer Ethnocentrism: A Literature Review. International Journal of Business and Management Invention. 2(5). pp. 50-54

elaborated in this paper are age and level of education. Socio-psychological features that have been covered in this research are the interest to travel abroad and foreign travel experience.

Alsughayir (2013) (2013) made a literature review regarding the consumers' ethnocentric antecedents. That review is complemented with additional researches that explored this topic presented in Table 1.

\section{HYPOTHESES}

Focusing on demographic and sociopsychological antecedents of $\mathrm{CE}$, the following hypotheses are proposed.

\subsection{Age}

Based on previous literature, it can be said that older people are generally more conservative and patriotic. Studies have shown that older consumers are more inclined to ethnocentric purchasing behaviour compared to younger population, i.e. consumers' ethnocentric tendencies increase with age (Klein \& Ettenson, 1999; Good \& Huddleston, 1995; McLain \& Sternquist, 1991; Caruana \& Magri, 1996). Many academics have shown that older population is more prone to ethnocentric buying behaviour compared to younger population (Matić, 2012; Nadiri \& Tümer, 2010; Klein \& Ettenson, 1999; Good \& Huddleston, 1995; McLain \& Sternquist, 1991; Caruana \& Magri, 1996; Balabanis et al., 2001; Jain \& Jain, 2013; Javalgi et al., 2005). Sharma et al. (1995) did not find a positive and significant relationship between age and ethnocentric tendencies. Siamagaka \& Balabanis (2015) also did not establish the existence of a significant link between $\mathrm{CE}$ and age.

There were also studies that found that customers under 30 demonstrated somewhat high CE, along with people over 51 who had the most expressed CE (Nadiri \& Tümer, 2010); there have also been studies that have found no significant relationships between CE and some age groups (Good \& Huddleston, 1995). 
Management, Vol. 23, 2018, No.2, pp. 47-64

A. Kvasina, B. Crnjak-Karanovic, A. Tucak: THE IMPACT OF DEMOGRAPHIC AND...

Even though Shankarmahesh (2006), by reviewing the $\mathrm{CE}$ literature with respect to age, concluded that empirical evidence was mixed, they did not find the empirical backing for this reasoning. Namely, Josiassen et al. (2011) verified the veracity of studies that had been cited in the literature for a long time (Bannister \& Saunders, 1978; Schooler, 1971; in Josiassen et al., 2011), stating that younger consumers are more ethnocentric than older ones, and found out that neither of those studies conclusively proved the aforementioned statement. Several additional studies reported the same results; however, they were also relying on empirical support of the two aforementioned studies (Josiassen et al., 2011. Therefore, it can be argued that there is more than enough evidence to suggest that younger age groups have less pronounced tendencies of CE (Josiassen et al., 1999).

H1: There are differences in the consumers' ethnocentric tendencies with regard to age.

\subsection{Level of education}

Previous research on the link between the level of education and consumers' ethnocentric tendencies have found a negative correlation, meaning individuals with lower levels of education exhibit greater ethnocentric tendencies (Erdogan \& Uzkurt, 2010; Caruana \& Magri, 1996; Matić, 2012; Klein \& Ettenson, 1999; Good \& Huddleston, 1995; Sharma et al., 1995; McLain \& Sternquist, 1991). Such results are explained by the fact that highly educated consumers will be open to accepting different cultural customs and other country's values, as well as the products from those countries. On the other hand, consumers with lower level of education, due to their lack of knowledge and experience, will demonstrate strong ethnocentric preferences, avoiding the purchase of foreign products.
Nadiri \& Tümer (2010) discovered significant differences in $\mathrm{CE}$ with respect to the level of education, namely, the consumers from Turkey with postgraduate degrees (master's degrees and doctorates) had the highest levels of ethnocentric tendencies, which Acikdilli et al. (2018) explained that could occur due to unique regional factors. There were also researches in which the findings showed no connection between CE and level of education (Jain \& Jain, 2013; Javalgi et al., 2005)..

In Croatia, the government supervises the educational system that has a centralized curriculum. From a young age, children learn about different cultures and learn foreign languages. Based on Javalgi et al. (2005), it can be stated that, if consumers have higher levels of education, they will be more open to recognize the value of foreign products.

Therefore, considering the level of education, most of the findings (Klein \& Ettenson, 1999; Good \& Huddleston, 1995; McLain \& Sternquist, 1991; Matić, 2012; Caruana \& Magri, 1996) showed a negative relationship between education and ethnocentric tendencies.

H2: There are differences in the consumers' ethnocentric tendencies with regard to the level of education.

\subsection{Interest to travel abroad}

The interest to travel abroad is a result of a positive attitude toward exposure to foreign countries and their characteristics, which can be achieved by watching television or in school (Nijssen et al., 1999). The interest to travel abroad is reflected in greater openness towards buying foreign products, meaning there is a negative correlation with CE.

Acceptance of foreign products affects the interest to travel abroad, which creates 
a positive attitude towards the products' country of origin and creates an interest to travel to that country. Therefore, the interest in foreign travel should have a negative correlation with consumers' ethnocentric tendencies (Alsughayir, 2013).

H3: There are differences in the consumers' ethnocentric tendencies with regard to the interest to travel abroad.

\subsection{Foreign travel experience}

Research findings show that foreign travel experience leaves the greatest trace in learning about one's culture and foreign countries. Therefore, consumers' ethnocentric tendencies could also be explained by the lack of travel experience or lack of information about other cultures, rather than bias (Mooij, 1997; in Alsughayir, 2013), which was also confirmed by Nijssen et al. (1999).

Traveling reduces the distance between cultures and strongly influences consumers' attitudes (Alsughayir, 2013). Nijssen et al. (1999) indicated that foreign travel experience has the most intense impact on other culture's knowledge, learning about their lifestyle and increasing the acceptance of products from that country, which indicates that travel to foreign countries should reduce ethnocentric tendencies. Shankarmahesh (2006) finds that, by better understanding different cultures, a person can develop better attitudes about his/her culture and that can cause higher CE.

People from small countries are generally more exposed to the influence of other cultures and hence less ethnocentric (Nijssen et al., 1999), meaning that, according to previous findings, Croatian consumers should have lower degree of ethnocentrism.

Sharma (1995) defines cultural openness as the will to interact with people from other cultures that can reduce possible cultural prejudice. A research conducted in France by Javalgi et al. (2005) suggests that there is no connection between cultural openness and consumers' ethnocentric tendencies. Moreover, Neuliep et al. (2001), in their study of CE among American and Japanese students, found out that travel experience did not have a significant effect on $\mathrm{CE}$. Jain \& Jain (2013) also did not find a significant link between CE and foreign travel experience.

H4: There are differences in the consumer ethnocentric tendencies with regard to foreign travel experience.

Literature review has revealed differences in previous researches due to the effect of cultural and economic factors or due to consumers' individual attitudes in a dynamic environment. Therefore, there is a need for further research in this area (Matić, 2012). Since studies have suggested that cultural distance is a significant factor in $\mathrm{CE}$ research, it is important to mention studies on CE carried out in the countries that are close to Croatia, both geographically and culturally. For example, studies were conducted in Slovenia (Vida \& Damjan, 2000; Dmitrovic et al., 2009), Bosnia and Herzegovina (Dmitrovic et al., 2009), Montenegro (Dmitrovic \& Vida, 2007; Dmitrovic et al., 2009 and Serbia (Dmitrovic \& Vida, 2007; Dmitrovic et al., 2009). The link between demographic and socio-physiologic factors and consumer ethnocentric tendencies has been researched in the region of Northern Croatia (Matić, 2012). However, researching only one region is not enough to create a country's consumer profile, which points out the necessity of this research in the domain of consumer behaviour with respect to consumers' ethnocentric tendencies. 


\section{METHODOLOGY}

The following chapter will elaborate on the sample, data collection, instrument, measures, and research data analysis.

\subsection{Sample}

The research was conducted on a sample of 420 respondents. The sample structure is shown in Table 2.

Table 2. Sample structure

\begin{tabular}{|c|c|c|}
\hline Characteristics & $\begin{array}{l}N \text { (out of } \\
\text { total) }\end{array}$ & $\begin{array}{c}\text { Percentage } \\
(\%)\end{array}$ \\
\hline \multicolumn{3}{|l|}{ Age } \\
\hline $19-28$ & 102 & $24.3 \%$ \\
\hline $29-35$ & 101 & $24.0 \%$ \\
\hline $36-48$ & 120 & $28.6 \%$ \\
\hline $49-69$ & 97 & $23.1 \%$ \\
\hline \multicolumn{3}{|l|}{ Level of education } \\
\hline $\begin{array}{l}\text { Three-year } \\
\text { vocational school }\end{array}$ & 35 & $8.33 \%$ \\
\hline $\begin{array}{l}\text { Four-year vocational } \\
\text { school }\end{array}$ & 97 & $23.10 \%$ \\
\hline High school & 74 & $17.62 \%$ \\
\hline $\begin{array}{l}\text { Undergraduate } \\
\text { programme }\end{array}$ & 53 & $12.62 \%$ \\
\hline $\begin{array}{l}\text { Graduate programme, } \\
\text { Academy, University } \\
\text { College }\end{array}$ & 145 & $34.52 \%$ \\
\hline $\begin{array}{l}\text { Doctorate, Masters' } \\
\text { degree }\end{array}$ & 16 & $3.81 \%$ \\
\hline \multicolumn{3}{|l|}{ Interest to travel abroad } \\
\hline $\begin{array}{l}\text { Does not want to travel, } \\
\text { Weak interest to travel, } \\
\text { Medium interest to travel }\end{array}$ & 77 & $18.3 \%$ \\
\hline Has interest to travel & 114 & $27.1 \%$ \\
\hline Strong interest to travel & 229 & $54.5 \%$ \\
\hline \multicolumn{3}{|l|}{ Foreign travel experience } \\
\hline $1-4$ & 104 & $24.8 \%$ \\
\hline $5-6$ & 106 & $25.2 \%$ \\
\hline $7-9$ & 109 & $26.0 \%$ \\
\hline $10-$ & 101 & $24.0 \%$ \\
\hline
\end{tabular}

Source: Research findings $(N=420)$

\subsection{Data collection}

The research was conducted in April 2017 in respondents' households or in public places in 6 towns, by authors' direct contact with respondents using a questionnaire. A deliberate quota pattern was used, a visible feature being a place of residence or a city.

\subsection{Instrument, measures and data analysis}

A highly structured questionnaire was used in this study. The questionnaire consisted of two parts. The first part contained CETSCALE measurement with five-degree Likert scale, and the second part contained demographic and socio-psychological questions.

The survey questionnaire was based on the original CETSCALE questionnaire (Shimp \& Sharma, 1987). Since the study was conducted in Croatia, the recommended cross-translation procedures were implemented (Brislin \& Anderson, 1976; Craig \& Douglas, 2000) in order to assure the accuracy of translation. For measuring consumers' ethnocentric tendencies, CETSCALE - Consumer Ethnocentric Tendencies Scale was used. The scale assumes that consumers' positive attitudes towards domestic products are a way to express national loyalty (Acikdilli et al., 2018). The scale examines $\mathrm{CE}$ tendencies using the Likert five-degree scale ( 1 = strongly disagree, $5=$ strongly agree).

The validity of CETSCALE has been confirmed by numerous international researches (Netemeyer et al., 1991; Good \& Huddleston, 1995; McLain \& Sternquist, 1991; Vida \& Reardon, 2008; Dmitrovic et al., 2009; Bawa, 2004; Jain \& Jain, 2013; Vida \& Fairhurst, 1999. CETSCALE has also been shown as a quality tool for measuring consumers' ethnocentric tendencies in Croatia (Renko et al., 2012; Dmitrovic \& 
Vida, 2007; Matić, 2012; Dmitrovic et al., 2009).

CETSCALE indicates to what extent consumers express anxiety towards purchasing foreign products, that buying such products is considered an unpatriotic and immoral act and, at the same time, has negative effects on the domestic economy (Matić, 2012). The originally developed scale has 17 statements in total (Shimp \& Sharma, 1987). In some research studies (Jain \& Jain, 2013) shortened scaling models were used with nine statements which also proved to be a quality instrument in measuring consumer ethnocentric tendencies. There are also authors that used the CETSCALE with ten items such as Dmitrovic \& Vida (2007), while Klein (2002) included only three statements for the purpose of measuring ethnocentric tendencies. The aforementioned indicates that CETSCALE could be context-dependent, which is why it is important to verify the suitability of the measurement scale in the research context. Acikdilli et al. (2018) also point out that CETSCALE does not have the same strength in all countries, yet its intensity rests on the level of country's economic development indicating the importance of testing and verifying the scale in each research setting.

In the second part of the questionnaire, two questions were related to demographic characteristics. Age was examined with the year of birth and the level of education was examined with listed categories of various degrees of education. Two questions were related to measuring socio-psychological characteristics. The interest to travel abroad was examined by asking question "Do you want to travel to foreign countries?" with a possibility to answer it on a 5-degree Likert scale ranging from 1 (Strongly against traveling abroad) to 5 (Strong wish to travel abroad). Foreign travel experience was measured with the number of visited foreign countries.

\section{FINDINGS}

The validity of the CETSCALE was tested using a confirmatory factor analysis. Both validity and reliability have been verified. In order to measure the effect of demographic and socio-psychological characteristics on the consumer ethnocentric tendencies, ANOVA was used. The data obtained by primary research were analysed in the SPSS (Statistical Package for Social Sciences).

The Cronbach's Alpha coefficient was used to determine the reliability of the CETSCALE. The Table 3 presents the reliability results of CETSCALE used indicating a high level or reliability.

Table 3. Reliability of CETSCALE

\begin{tabular}{|c|c|}
\hline Number of variables & Cronbach's Alpha \\
\hline 17 & .971 \\
\hline
\end{tabular}

Source: Research findings $(N=420)$

The sample analysis was tested using the Kaiser-Meyer-Olkin test and Bartlett's test. The adequacy of the sample is appropriate $(\mathrm{KMO}=0.97)$ and Bartlett's test is statistically significant $(\alpha \leq 0.05)$ indicating that this variable was appropriate for conducting the factor analysis. The number of factors was determined using the Kaiser-Guttman criterion. According to the Kaiser-Guttman criterion, the model should include only those factors that have eigenvalues greater than 1 .

The factor extraction method used was PCA - Principal Components Analysis. Two factors were separated with values greater than 1 . Two factors together account for $74.2 \%$ of the total variance. Factor 1 
Table 4. Ungrouped Factor Structure Matrix for CETSCALE

\begin{tabular}{|l|c|}
\hline \multicolumn{1}{|c|}{ Items } & Component \\
\cline { 2 - 2 } & $\mathbf{1}$ \\
\hline Croatian people should always buy Croatian products. & .830 \\
\hline Only those products that are unavailable in Croatia should be imported. & .747 \\
\hline Buy Croatian products. Keep Croatia working. & .752 \\
\hline Croatian products, first, last, and foremost. & .807 \\
\hline Purchasing foreign-made products is un-Croatian. & .850 \\
\hline It is not right to purchase foreign products, because it puts Croatian people out of a job. & .853 \\
\hline A true Croatian should always buy Croatian-made products. & .871 \\
\hline $\begin{array}{l}\text { We should purchase products manufactured in Croatia instead of letting other countries get rich } \\
\text { off of us. }\end{array}$ & .865 \\
\hline It is always best to purchase Croatian products & .845 \\
\hline $\begin{array}{l}\text { There should be very little trading or purchasing of goods from other countries unless out of } \\
\text { necessity. }\end{array}$ & .834 \\
\hline $\begin{array}{l}\text { Croatians should not buy foreign products, because this hurts Croatian business and causes } \\
\text { unemployment. }\end{array}$ & .874 \\
\hline Curbs should be put on all imports. & .777 \\
\hline It may cost me in the long run but I prefer to support Croatian products. & .785 \\
\hline Foreigners should not be allowed to put their products on our market. & .828 \\
\hline Foreign products should be taxed heavily to reduce their entry into Croatia. & .813 \\
\hline $\begin{array}{l}\text { We should buy from foreign countries only those products that we cannot obtain within our own } \\
\text { country. }\end{array}$ & .856 \\
\hline $\begin{array}{l}\text { Croatian consumers who purchase products made in other countries are responsible for putting } \\
\text { their fellow Croatians out of work. }\end{array}$ & .837 \\
\hline
\end{tabular}

Source: Research findings $(N=420)$

explains $68.2 \%$ of the total variance, while Factor 2 explains $6 \%$ of the total variance. Varimax rotation was not used because all manifested variables show significant loading on Factor 1 (>0.7).

Using the PCA method, calculated factor loadings range from 0.747 to 0.874 , which indicates a high loading of the variables on the explained isolated factor. The presented factor structure suggests that the CETSCALE has both convergent and discriminatory validity. Based on the responses, the distinguished factor is named "consumer ethnocentrism". The ungrouped factor structure matrix containing factor loadings is shown in Table 4.

The analysis of demographic and sociopsychological characteristics on consumers' ethnocentric tendencies was conducted using ANOVA with one variable factor and the results are presented in Table 5.

Table 5. Results from ANOVA - Demographic and socio-psychological characteristics and consumers' ethnocentric tendencies

\begin{tabular}{|l|l|l|}
\hline & F & Sig. \\
\hline Age & 23.179 & .000 \\
\hline Level of education & 12.209 & .000 \\
\hline Interest to travel abroad & 11.473 & .000 \\
\hline Foreign travel experience & 4.554 & .004 \\
\hline
\end{tabular}

Source: Research findings $(N=420)$

In addition, Scheffe post hoc tests were conducted for each variable in order to find out between which groups exist differences. The statistically significant differences between groups $(\alpha \leq 0.05)$ are shown in Table 6. 
Journal of Contemporary Management Issues

Table 6. Results from Scheffe Post hoc Tests - Differences between researched groups

\begin{tabular}{|c|c|c|c|c|}
\hline Variables/groups & Groups & $\begin{array}{l}\text { Mean } \\
\text { difference }\end{array}$ & $\begin{array}{l}\text { Standard } \\
\text { error }\end{array}$ & Sig. \\
\hline \multicolumn{5}{|l|}{ Age } \\
\hline $19-28$ & $\begin{array}{l}36-48 \\
49-69\end{array}$ & $\begin{array}{r}.39207 \\
1.08968\end{array}$ & $\begin{array}{l}.12939 \\
.13625\end{array}$ & $\begin{array}{l}.028 \\
.000\end{array}$ \\
\hline $29-35$ & $49-69$ & .83040 & .13658 & .000 \\
\hline $36-48$ & $\begin{array}{l}19-28 \\
49-69\end{array}$ & $\begin{array}{r}-.39207 \\
.69761\end{array}$ & $\begin{array}{l}.12939 \\
.13118\end{array}$ & $\begin{array}{l}.028 \\
.000\end{array}$ \\
\hline $49-69$ & $\begin{array}{l}19-28 \\
29-35 \\
36-48\end{array}$ & $\begin{array}{r}-1.08968 \\
-.83040 \\
-.69761\end{array}$ & $\begin{array}{l}.13625 \\
.13658 \\
.13118\end{array}$ & $\begin{array}{l}.000 \\
.000 \\
.000\end{array}$ \\
\hline \multicolumn{5}{|l|}{ Level of education } \\
\hline Three-year vocational school & High school & -.69984 & .20107 & 018 \\
\hline Four- year vocational school & $\begin{array}{l}\text { High school } \\
\text { Graduate programme, } \\
\text { Academy, University } \\
\text { College, Doctorate, } \\
\text { Masters' degree }\end{array}$ & -.71513 & .15128 & .000 \\
\hline High school & $\begin{array}{l}\text { Three-year vocational } \\
\text { school } \\
\text { Four-year vocational school }\end{array}$ & $\begin{array}{l}.69984 \\
.92410\end{array}$ & $\begin{array}{l}.20107 \\
.15128\end{array}$ & $\begin{array}{l}.018 \\
.000\end{array}$ \\
\hline $\begin{array}{l}\text { Graduate programme, Academy, } \\
\text { University College, Doctorate, } \\
\text { Masters' degree }\end{array}$ & Four-year vocational school & .71513 & .12856 & .000 \\
\hline \multicolumn{5}{|l|}{ Interest to travel abroad } \\
\hline $\begin{array}{l}\text { Does not want to travel. Weak } \\
\text { interest to travel. Medium inter- } \\
\text { est to travel }\end{array}$ & Strong interest to travel & -.62021 & .13296 & .000 \\
\hline Strong interest to travel & $\begin{array}{l}\text { Does not want to travel. } \\
\text { Weak interest to travel. } \\
\text { Medium interest to travel }\end{array}$ & -.62021 & .13296 & .000 \\
\hline \multicolumn{5}{|l|}{ Foreign travel experience } \\
\hline $1-4$ & $10-$ & -.50895 & .14267 & .006 \\
\hline $5-6$ & $10-$ & -.35704 & .14201 & .099 \\
\hline $10-$ & $\begin{array}{l}1-4 \\
5-6\end{array}$ & $\begin{array}{l}.50895 \\
.35704\end{array}$ & $\begin{array}{l}.14267 \\
.14201\end{array}$ & $\begin{array}{l}.006 \\
.099\end{array}$ \\
\hline
\end{tabular}

Source: Research findings $(N=420)$ 


\section{DISCUSSION}

Research results confirmed hypothesis H1, i.e. there are significant differences in the consumers' ethnocentric tendencies in relation to age.

Respondents aged 19 to 28 show the greatest tendencies of $\mathrm{CE}$, followed by people aged 29 to 35 , then by those aged from 36 to 48 , and at the end, with the least expressed tendencies, are 49 to 69-year-old respondents. Research findings show that the youngest population has the most prominent tendencies of CE, while the oldest population has the least expressed tendencies of CE. These findings differ from most studies that indicate that older population has significant tendencies of $\mathrm{CE}$.

Hypothesis H2 was also confirmed, showing significant differences in consumers' ethnocentric tendencies regarding the level of education. Moreover, tendencies of $\mathrm{CE}$ are more pronounced in the group of high school graduates and people with higher levels of education. Since the results showed that more educated people expressed greater tendencies of $\mathrm{CE}$, this finding also differs from the general findings regarding the link between these variables.

Increasing tendencies of $\mathrm{CE}$ are observed among people with high school, college, or higher education, while they are less pronounced among those who completed a three-year or four-year vocational high school. An explanation of such results may lie in the fact that consumers who are more educated have more information and show greater awareness of the usefulness of buying domestic products.

Findings supported hypothesis H3, showing significant differences in consumers' ethnocentric tendencies regarding interest to travel abroad. It is important to mention that there were only a few respondents who stated they did not want to visit foreign countries (only 3 respondents said they did not want to travel and 10 respondents stated they had no interest to travel abroad). These responses were merged with responses of respondents who stated a small interest in visiting foreign countries and were tested as one group that has a lower inclination to travel abroad. The tendencies of $\mathrm{CE}$ are most pronounced among people who have a strong interest in foreign travel, yet another result that contradicts previous findings in this area.

Research results show that increased interests in traveling abroad are connected with increased tendencies of CE. The interest in traveling abroad, the will to interact with people from other culture, and the desire for learning and self-improvement can affect the positive link between CE and interest to travel.

Hypothesis H4 was also confirmed, demonstrating significant differences in the consumer ethnocentric tendencies with regard to foreign travel experience. The respondents were categorized in four groups: 1-4 travels, 5-6 travels, 7-9 travels and 10 or more travels to foreign countries. The results show that consumers' ethnocentric tendencies are most pronounced in the group of respondents that have visited 10 or more foreign countries, which also represents an interesting finding when comparing it to previous researches. The results show that larger numbers of visited countries also increase their ethnocentric tendencies. This can possibly be explained with a better understanding of different cultures; an individual can adopt more favourable attitudes about his or her culture and thereby develop $\mathrm{CE}$ as proven by the research. 


\section{CONCLUSIONS}

The research determined the level of intensity of consumers' ethnocentric tendencies in the area of Split-Dalmatia County, Croatia in order to enable the creation of a consumer profile. The findings of the study confirmed the existence of differences in consumers' ethnocentric tendencies between groups regarding various demographic and socio-psychological characteristics. However, when observing those differences among groups, the findings differ from previous research in the area of CE. Regarding demographic variables, the results showed that younger consumers and respondents with higher level of education have more expressed tendencies of CE. As for the socio-psychological characteristics, the results showed that respondents who have more expressed interest to travel abroad, as well as the ones that have more foreign travel experience, tend to have higher pronounced consumers' ethnocentric tendencies.

\subsection{Theoretical and practical implications}

As Acikdilli et al. (2018) pointed out, it is important to measure $\mathrm{CE}$ in order to make optimal international marketing decisions. The study examined the intensity of consumers' ethnocentric tendencies and compared them with two demographic characteristics: age and level of education, as well as two socio-psychological characteristics: interest to travel abroad and foreign travel experience.

This study also contributes to $\mathrm{CE}$ literature by validating CETSCALE measurement in a new research setting - Split-Dalmatia County, Croatia, as well as by measuring the consumers' ethnocentric tendencies in that research context. Furthermore, since it examined the influence of demographic and socio-psychological characteristics on ethnocentric tendencies in this chosen research setting, it contributes to fulfilling the consumer profile of Split-Dalmatia County, as well as that of Croatian market.

Research findings provide domestic and foreign manufacturers and service providers with valuable information on the consumer profile of Split-Dalmatia County. Research findings also provide answers to some questions in creating a product positioning strategy. For example, since CE is a complex concept and it is not easily reduced, the companies that want to sell their products in the Croatian market can try to change their positioning strategy according to the findings, by selecting the optimal segment of consumers given the offered product and the characteristics of targeted consumers in this market.

The paper confirms research findings regarding the existence of high correlation of CE with the demographic and sociopsychological characteristics of consumers. The results of the research can provide additional insights into domestic producers on the ethnocentric profile of consumers in specific cities in Split-Dalmatia County and throughout the county. Therefore, the results can facilitate the process of product and service providers better positioning in the market, as well as creating a competitive advantage on the domestic market, among domestic consumers, at times when foreign competition is increasingly threatening the market position of domestic product and service providers. The consumer characteristics identified by this research can serve as guidelines that companies can and should put in the context of their business with the aim of improving their consumer knowledge.

Another thing that needs to be taken into consideration is the trend of EU 
developing a 'European' image that can give companies that are located in the EU member countries, a competitive advantage when selling their products or offering their services to ethnocentric consumers (Javalgi et al., 2005).

The results of the study can also be a starting point for deciding on the potential for standardization or need for adaptation in an already established ethnocentric market. It is important to understand the trends in consumers' ethnocentric tendencies in order to make or verify market segmentation in the given market.

\subsection{Limitations}

The research has several limitations that should be taken into account in further research. The limitation is the use of a deliberate quota sample, because of which the results cannot refer to the entire population. Also, in order to be able to use the ANOVA method, the responses were categorized in groups. Therefore, better results could be obtained by conducting an in-depth analysis

\section{References}

1. Acikdilli, G., Ziemnowicz, C., \& Bahhouth, V. (2018). Consumer Ethnocentrism in Turkey: Ours are Better than Theirs. Journal of International Consumer Marketing, 30(1), 45-57.

2. Alshammari, E., Williams, M., \& Morgan, N. (2017). Integrative review: Factors effecting consumer ethnocentrism (CET). International Review of Management and Business Research, 6(2), 579-594.

3. Alsughayir, A. (2013). Consumer Ethnocentrism: A Literature Review. International Journal of Business and Management Invention, 2(5), 50-54.

4. Balabanis, G., \& Siamagka, N.T. (2017). Inconsistencies in the of each respondent's group that could be done by increasing the sample size.

Since only several demographic and socio-psychological characteristics are covered in this research, a further research should also address other demographic and socio-psychological variables in order to enrich the knowledge of consumer profile of the Split-Dalmatia County, as well as of the entire Croatian market.

Furthermore, it would be worthwhile to investigate the impact of consumers' ethnocentric tendencies with regard to the intention to purchase different product categories. Since many studies have found that product category is an important antecedent of CE, it would be interesting to find out whether that connection exists in this research setting, due to contradictory findings of this study. It is our hope that future research and an in-depth analysis of CE in this region could help clearing out the reasons why consumers in this region act according to the findings.

behavioural effects of consumer ethnocentrism: The role of brand, product category and country of origin. International Marketing Review, 34(2), 166-182.

5. Balabanis, G., Diamantopoulos, A., Mueller, R., \& Melewar, T. (2001). The impact of nationalism, patriotism and internationalism on conusmer ethnocentric tendencies. Journal of International Business Studies, 32(1), 157-175.

6. Balabanis, G., Mueller, R., \& Melewar, T. (2002). The relationship between consumer ethnocentrism and human value. Journal of Global Marketing, 15(34), 7-37.

7. Bawa, R. (2004). Consumer ethnocentrism: CETSCALE Validation and Measurement of Extent. Vikalpa: The 
Journal for Decision Makers, 29(3), 43-58.

8. Brislin, R., \& Anderson, R. (1976). Translation: Applications and Research. New York: Gardner Press: distributed by Halsted Press.

9. Caruana, A., \& Magri, E. (1996). The effect of dogmatism and social class variables on consumer ethnocentrism in Malta. Marketing Intelligence \& Planning, 14(4), 39-44.

10. Craig, C., \& Douglas, S. (2000). International Marketing Research. London: Wiley.

11. Crawford, J., Lamb, \& C.W. (1981). Source preferences for imported products. Journal of Purchasing and Materials Management, Winter, 28-33.

12. Crnjak-Karanović, B., \& Miočević, D. (2013). Osnove međunarodnog marketinga (1st edition ed.). Split: Sveučilište u Splitu, Ekonomski fakultet.

13. Dmitrovic, T., \& Vida, I. (2007). An examination of cross-border shopping behaviour in South-East Europe. European Journal of Marketing, 41(3/4), 382-395.

14. Dmitrovic, T., Vida, I., \& Reardon, J. (2009). Purchase behavior in favor of domestic products in the West Balkans. International Business Review, 18, 523-535.

15. Erdogan, B., \& Uzkurt, C. (2010). Effects of ethnocentric tendency on consumers' perception of product attitudes for foreign and domestic products. Cross Cultural Management: An International Journal, 17(4), 393-406.

16. Good, L., \& Huddleston, P. (1995). Ethnocentrism of Polish and Russian consumers: are feelings and intentions related. International Marketing Review, 12(5), 35-48.
17. Han, C. M. (2016). Cosmopolitanism and ethnocentrism among young consumers in emerging Asia: Chinese vs Koreans towards Japanese brands. Asia Pacific Journal of Marketing and Logistics, 29(2), 330-346.

18. Jain, S., \& Jain, R. (2010). Consumer Ethnocentrism, Its Antecedents an Consequences to Consumer Attitudes towards Domestic and Foreign Made Products: A Theoretical Framework. Business Analyst, 31(1), 23-46.

19. Jain, S., \& Jain, R. (2013). Consumer Ethnocentrism and Its Antecedents: An Exploratory Study of Consumers in India. Asian Journal of Business Research, 3(1), 1-18.

20. Javalgi, R., Khare, V., Gross, A., \& Scherer, R. (2005). An application of the consumer ethnocentrism model to French consumers. International Business Review, 14, 325-344.

21. Josiassen, A., Assaf, A. G., \& Karpen, I. O. (2011). Consumer ethnocentrism and willingness to buy: Analyzing the role of three demographic consumer characteristics. International Marketing Review, 28(6), 627-646.

22. Klein, J. (2002). Us Versus Them, or Us Versus Everyone? Delineating Consumer Aversion to Foreign Goods. Journal of International Business Studies, 33(2), 345-363.

23. Klein, J., \& Ettenson, R. (1999). Consumer Animosity and Consumer Ethnocentrism. Journal of International Consumer Marketing, 11(4), 5-24.

24. Klein, J., Ettenson, R., \& Morris, M. (1998). The Animosity Model of Foreign Product Purchase: An Empirical Test in the People's Republic of China. Journal of Marketing, 62(1), 89-100.

25. Matić, M. (2012). Ispitivanje utjecaja demografskih čimbenika na tendencije 
potrošačkog etnocentrizma u Sjevernoj Hrvatskoj. Praktični menadžment, 3(4), 27-33.

26. McLain, S., \& Sternquist, B. (1991). Ethnocentric Consumers. Journal of International Consumer Marketing, 4(12), 39-58.

27. Mooij, M., \& Hofstede, G. (2002). Convergence and divergence in consumer behavior: implications for international retailing. Journal of Retailing, 78, 61-69.

28. Nadiri, H., \& Tümer, M. (2010). Influence of ethnocentrism on consumers' intention to buy domnestically produced goods: An empirical study in North Cyprus. Journal of Business Economics and Management, 11(3), 444-461.

29. Netemeyer, R., Durvasula, S., \& Lichtenstein, D. (1991). A CrossNational Assessment of the Reliability and Validity of the CETSCALE. Journal of Marketing Research, 28(3), 320-327.

30. Neuliep, J., Chaudoir, M., \& McCroskey, J. (2001). A cross-cultural comparison of ethnocentrism among Japanese and United States college students. Communication Research Reports, 18(2), 137-146.

31. Nijssen, S., Douglas, P., \& Bressers, P. (1999). Attitudes toward the purchase of foreign products: extending the model. In A. o. Marketing (Ed.), AMA Global Marketing SIG Joint Conference.

32. Renko, N., Crnjak Karanović, B., \& Matić, M. (2012). Influence of consumer ethnocentrism on purchase intentions: case of Croatia. Ekonomska misao i praksa, XXI(2), 529-544.

33. Shankarmahesh, M. (2006). Consumer ethnocentrism: an integrative review of its antecedents and consequences. International Marketing Review, 23(2), 146-172.
34. Sharma, S., Shimp, T., \& Shin, J. (1995). Consumer ethnocentrism: A test of antecedents and moderators. Journal of the Academy of Marketing Science, 23(1), 26-37.

35. Shimp, T. (1984). Consumer Ethnocentrism: the Concept and a Preliminary Empirical Test. Advances in Consumer Research, 11, 285-290.

36. Shimp, T., \& Sharma, S. (1987). Consumer ethnocentrism: Construction and validation of the CETSCALE. Journal of Marketing Rersearch, 24(3), 280-289.

37. Siamagka, N.-T., \& Balabanis, G. (2015). Revisiting Consumer Ethnocentrism: Review, Reconceptualization, and Empirical Testing. Journal of International Marketing, 23(3), 66-86.

38. Vida, I., \& Damjan, J. (2000). The Role of Consumer Characteristics and Attitudes in Purchase Behavior of Domestic versus Foreign Made Products: The Case of Slovenia. Journal of East-West Business, 6(3), 111-133.

39. Vida, I., \& Reardon, J. (2008). Domestic consumption: rational, affective or normative choice? Journal of Consumer Marketing, 25(1), 34-44.

40. Vida, L., \& Fairhurst, A. (1999). Factors underlying the phenomenon of consumer ethnocentricity: evidence from four central European countries. The International Review of Retail, Distribution and Consumer Research, 9(4), 321-337.

41. Watson, J., \& Wright, K. (2000). Consumer ethnocentrism and attitudes toward domestic and foreign products. European Journal of Marketing, 34(9/10), 1149-1166. 


\section{UTJECAJ DEMOGRAFSKIH I SOCIO-PSIHOLOŠKIH OBILJEŽJA NA ETNOCENTRIČNOST POTROŠAČA: DOKAZI IZ HRVATSKE}

\section{Sažetak}

Ciljovog rada je utvrditi utjecaj demografskih i socio-psiholoških karakteristika na etnocentričke tendencije potrošača. Istraživanje je provedeno u Hrvatskoj, među stanovnicima Splitskodalmatinske županije. Podaci su prikupljeni od 420 ispitanika, korištenjem mjere CETSCALE. Provedeno je testiranje hipoteza, s ciljem utvrđivanja razlika u etnocentričnim tendencijama potrošača, s obzirom na dva demografska obilježja (dob i razina obrazovanja), kao i dvoje socio-psihološka obilježja (iskustvo s putovanjima u inozemstvo i interes za isto). Obje hipoteze, koje se odnose na dob i obrazovanje su prihvaćene. Štoviše, rezultati pokazuju da ispitanici s višom razinom obrazovanja imaju izraženije tendencije prema potrošačkom etnocentrizmu od ispitanika $s$ nižom razinom obrazovanja. Rezultati, također, pokazuju da je tendencija prema potrošačkom etnocentrizmu izraženija kod mlađih ljudi, što je u suprotnosti s prethodnim istraživanjima. Obje hipoteze, koje se odnose na socio-psihološka obilježja, također su potvrđene. Istraživanje ukazuje da ljudi, koji više putuju u inozemstvo te imaju veći interes za isto, u većoj mjeri teže potrošačkom etnocentrizmu od onih, koji manje putuju $i$ imaju manji interes za putovanja u inozemstvo.

Ključne riječi: etnocentrizam, potrošači, demografija, socio-psihološke karakteristike, putovanja 